[Vicino Oriente XIX (2015), pp. 65-84]

\title{
AL-FUDAYN: AN UMAYYAD RESIDENCE IN NORTHERN JORDAN
}

\author{
Giuseppe Labisi - Sapienza University of Rome
}

The site of al-Fudayn, to the northeast of 'Ammān and including a mosque, some residential units and baths, is part of the "developed" Umayyad residences; furthermore, the stucco decoration of the qibli wall plays an important role in the study of Umayyad art as it is the only example, as far as we know, that can be entirely reconstructed; the aim of this essay is to describe the site and suggest its dating through comparisons.

Keywords: Jordan; Umayyad residential architecture; Umayyad baths; stucco decoration; Syrian bayt

\section{INTRODUCTION}

The complex of al-Fudayn is located in the town of al-Mafraq - east of the Government Hospital, $70 \mathrm{~km}$ northeast of 'Ammān - coordinates 32²0'41.94"N, 36²12'2.14"E.

The first archaeological activities were carried out by the École Biblique et Archéologique Française de Jérusalem in 1986. The French scholars managed to carry out three short archaeological investigations which revealed a "stronghold" of the Iron Age under a Byzantine complex (Unit III, see below), and an Umayyad complex that reused the structures from the Byzantine period as well as two residential units (Unit I-II, see below); ${ }^{1}$ during the excavation of the Umayyad phase of the vestibule of the Byzantine complex the French archaeologists discovered a treasure of bronze objects, steatite vessels and carved ivory plaques and pyxides. ${ }^{2}$ From 1991 to 2001 the Department of Antiquities of Jordan carried out the excavation and restoration of the whole site, publishing two articles in Arabic. ${ }^{3}$ Archaeological activities at al-Mafraq are also mentioned in publications by the Spanish Archaeological Mission in Jordan; ${ }^{4}$ the site has been included in the recent publication by Denis Genequand, where a barrage is also mentioned. ${ }^{5}$

The scholars were also interested in the treasure discovered by the French archaeologists: ${ }^{6}$ these essays include the evidences collected at the site and a sketch plan. ${ }^{7}$ Finally, a good aerial photograph of the complex was published by D. Kennedy and R. Bewley. ${ }^{8}$

In April 2012 a short visit to the site was conducted by Valentina Cocciolo, and who writes; the aim of the visit was to gain a better understanding of the Umayyad archaeological evidences, but new unpublished data was also collected.

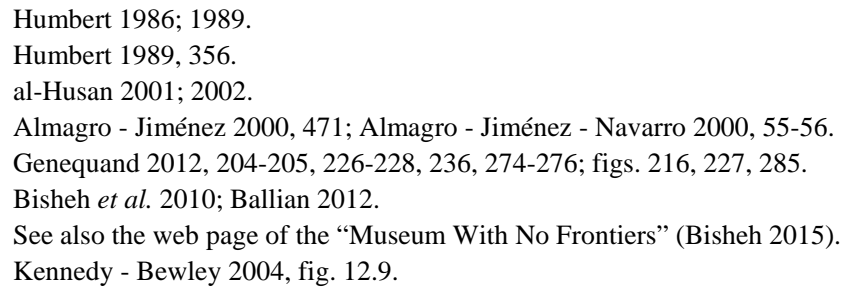




\section{ISLAMIC HISTORY OF AL-FUDAYN}

The Arabic name "al-Fudayn" reveals an Aramaic origin: it means "the stronghold". 9

The only available information about the Islamic al-Fudayn is connected with the descendents of the Caliph 'Uthmān. Sa'īd ibn Khālid ibn 'Amr ibn 'Uthmān ibn 'Affān, a member of the Umayyad clan, owned the complex, while his daughters were married to the Umayyad Caliphs Hishām ibn 'Abd al-Malik and al-Walīd ibn Yazīd. ${ }^{10}$

During the caliphate of al-Ma mūn a descendent of Sa'̄id ibn Khālid, his namesake Sa '̄id ibn Khālid al-Fudaynī, claimed the caliphate from him. Yāqūt refers that «when he was near his fortress known as al-Fudayn» he escaped from it moving to the south; Yāqūt then ended his account by saying «I do not know what happened to him», but it is likely that al-Fudayni was executed and his possessions destroyed. ${ }^{11}$ In any case, these events prove that up until the early $9^{\text {th }}$ century the complex of al-Fudayn was still owned by the descendants of the Umayyad family.

\section{THE ARCHAEOLOGICAL EVIDENCES}

The site is approximately $175 \mathrm{~m}$ southwest of the conjunction between the wādī Hinw al-Hișan to the south and the wādī al-Fudayn to the north, near a natural water source (fig. 1). ${ }^{12}$ Denis Genequand refers to the presence of a barrage almost $400 \mathrm{~m}$ northeast of the complex: it could be dated to the Umayyad period, but according to Genequand it was probably converted in modern times due to a different construction technique employed in the middle of the wall. ${ }^{13}$

According to the French archaeologists (see above) the site reveals five phases, dating from the Iron Age to the Islamic period.

The first phase corresponds to a "stronghold" of the Iron Age (dated to the $7^{\text {th }}$ century $\mathrm{BC}$ thanks to the ceramic evidences), of which the massive foundation wall is preserved; ${ }^{14}$ the second phase belongs to the Roman period: the excavators mention a Roman via with three miliaria in situ, indicating seven milia from the previous statio: this was most probably the statio of a variant of the Via Nova Trajana connecting Bostra to Gerasa; ${ }^{15}$ a miliarium bears the name of the emperor Caracalla and is precisely dated to $214 \mathrm{AD}$. $^{16}$ During the Byzantine period the ruins of the Iron Age "stronghold" were reused: due to the presence of a chapel and a reference in the Syriac sources the archaeologists interpreted the complex as a monastic compound (here too the chronological attribution is supported by the ceramic evidences). ${ }^{17}$

9 According to the French archaeologists the toponym was confirmed thanks to the discovery of three massive rows under the monastic complex which revealed a fortification (Humbert 1986, 354-355).

10 Bisheh 2015

11 Yāqūt 1866-1870, III vol, 859 (quoted in Grabar 1964, 44).

12 For the toponyms see http://www.geonames.org/maps/google_32.35_36.2.html (16/03/2015).

13 Genequand 2012, 274-276, fig. 285.

14 Cf. Genequand 2012, 274-276, fig. 285; Glueck 1942, 14, figs. 1-2; 1945-1949, 1.

15 Cf. Glueck 1945-1949, 356; see also Sapin 1998, 128.

16 Kennedy - al-Husan 1996, 259.

17 Humbert 1989, 126. 
The main section of the complex is dated to the Umayyad period thanks to the Umayyad treasure and ceramic evidences: during this period two residential units (Units I-II) were erected and the Byzantine complex was probably reused. ${ }^{18}$ Finally, the French archaeologists referred to an Ayyubid camp, but no further mention of it was made ${ }^{19}$ and the remains were not traced during our survey of 2012.

The purpose here is to describe the Umayyad phase of the complex, which reveals some important data.

\subsection{The Umayyad Phase}

The map of the Umayyad phase presented here (fig. 2) is a collation of the maps published by French and Jordanian excavators ${ }^{20}$ and by Genequand, ${ }^{21}$ the aerial photograph published by Kennedy and Bewley, ${ }^{22}$ the satellite image and the sketch plan drafted during our survey; the map was also checked against the photographs taken during the same survey.

The complex is composed of three terraces and occupies an area of almost $6400 \mathrm{~m}^{2}$.

\subsubsection{Unit I}

Unit I (38.97 $\times 38.27 \mathrm{~m}$; fig. 3) is composed of a central courtyard with fourteen surrounding rooms (including a mosque), and two structures to the north of it: the bath complex and a rectangular corridor connecting Unit I to Unit III. Unit I occupies an area of $1571.51 \mathrm{~m}^{2}$.

The central courtyard is almost a square of $20.5 \times 20.98 \times 21.98 \times 19.55 \mathrm{~m}$; the main entrance is on the east side and its doorway, opening to the interior of the complex, is about $2 \mathrm{~m}$ wide and has two door jambs. The door leads to a vestibule (Room 5), measuring 3.62 $\times 3.97 \mathrm{~m}$. On the southern side there are two rectangular rooms connected to the central courtyard: Room $1(10.19 \times 3.58 \mathrm{~m})$ and Room $2(6.72 \times 3.46 \mathrm{~m})$; Room 1 is also connected to the mosque. The southeastern side was modified in a post-Umayyad phase, but according to the orientation of the Umayyad walls we propose the reconstruction of two rooms: Room 3 (ca $8.31 \times 3.32 \mathrm{~m}$ ) and Room 4 (ca $3.95 \times 9.87 \mathrm{~m})$.

The southwestern side of the complex is occupied by the palace mosque (figs. $3-4):{ }^{23}$ it appears to show a rectangular plan of $7.31 \times 16.12 \mathrm{~m}$. A semicircular mihräb is located in the southern wall; it measures $1.18 \mathrm{~m}$ in width, $0.80 \mathrm{~m}$ in depth, and has two flanking and englobed columns. The original roofing has been ignored. The qibli wall was rendered with

8 Humbert 1986, 356-358, Bisheh et al. 2010, 134; Bisheh 2015.

19 Humbert 1986, 357.

20 Humbert 1989, figure at page 123; al-Husan 2001, figs. 6-7; 2002, fig. 4.

21 Genequand 2012, fig. 216.

22 Kennedy - Bewley 2004, fig. 12.9 .

23 al-Husan 2001, 8, figs. 6-7; 2002, 75-77, figs. 4-6; the case of al-Fudayn, although on a smaller scale, belongs to the few examples of Umayyad extra-urban residences with a palatine mosque, such as Khirbat al-Minya, Qașr al-Ḥayr al-Sharqī and Mshattā (Creswell 1979, 381-389, 579-606; Genequand 2012, 95-159) and, albeit in a different way, Khirbat al-Mafjar (Hamilton 1959; for a recent synthesis on the topic see the unpublished MA Thesis of Jasmina Žnidarec, 2014). 
stucco and decorated with geometric and vegetal patterns (for a complete description of the decoration see 2.3.1.). Jordanian archaeologists recognized a painted decoration in red, black, yellow and brown on the eastern wall of the mosque. ${ }^{24}$ The doorway on the north side connects the mosque to the palace through Room 7, while the doorway on the south side provides an entrance to the mosque from the outside and the doorway on the east side connects the mosque with Room 1; the southern and eastern doorways were closed in a later period; at present, the mosque has no direct access from the courtyard. Furthermore, according to the plan published by Jordanian archaeologists ${ }^{25}$ (fig. 4) and the autoptic analysis of the walls, at least five main phases related to the mosque can be recognized: phase I - the most ancient - consists of a wall oriented to about $2 \mathrm{~m} \mathrm{E-SE} \mathrm{/} \mathrm{W-NE} \mathrm{and}$ about $4.5 \mathrm{~m} \mathrm{E-W}$; this wall is significantly lower than the walls of phases II and III, abutting to the wall of phase I. Phase II consists of the qibli wall and a portion of the eastern and western walls for a length of ca $3.90 \mathrm{~m}$; the wall thickness is on average 1.20 $\mathrm{m}$. The southern and western doorways of the mosque can be attributed to this phase; the floor of phase II is composed of a layer of rubble stones covered by a thick layer of mortar. The walls of phase III are less thick than those of the other phases (ca $0.75 \mathrm{~m}$ ), displaying a change in the orientation of $4^{\circ}$ east compared to the orientation of the walls of phase II; the northern entrance of the mosque is attributable to this phase. Furthermore, the partition wall (fig. 4 - on the north side, orientation E-W) and the embedded pillars belong to this period, as the stratigraphic connection to the other walls of the same phase clearly reveals. The walls of phase III abut to those of phase I, and apparently have no stratigraphic connection to the walls of phase II. Phase IV (fig. 5) consists of a wall oriented E-W, not mentioned by Jordanian scholars; ${ }^{26}$ the first layer of the partition wall is composed of earth in contact with the floor, while the second layer is made up of reused blocks of limestone, generally square, compacted by an earth mortar and placed irregularly; the wall of phase IV abuts on the wall of phase III. Finally, in phase V the southern and eastern doorways were closed (fig. 5).

As concerns the dating, I believe that phase II can be dated to the Umayyad period: in fact the stucco decoration, which surely belongs to the Umayyad period (see below), can be attributed to the wall construction phase.

Room 7 (6.93 $\times 7.12 \mathrm{~m}$ ) has three entrances (fig. 3): one from the south (connecting the mosque), one from the west (connecting the central courtyard) and one from the north (connecting Room 8); the layer of rubble stones is still preserved along the sides of the room, but we do not know if it was covered by a layer of mortar as was the case in the mosque.

The northern part of the complex is occupied by Rooms 8-13, which are arranged according to the "Syrian bayt" plan, ${ }^{27}$ that is two central rooms (Room 10 and Room 13) with two rooms on each side - Room 8 and Room 9 to the east of Room 10, and Rooms 11 and 12 between Rooms 10 and Room 13; to the east of Room 13 there is an oblong room

24 al-Husan 2001, 8.

25 al-Husan 2002, fig. 4.

26 Cf. al-Husan 2002, fig. 4.

27 For a description of the "Syrian bayt" see Creswell 1979, 516-517. 
(Room 6: $3.93 \times 15.37 \mathrm{~m}$ ) that connects the bath complex to the other structures. North of the "Syrian bayt" there is a corridor communicating with Rooms 9 and 10 and connecting Unit I to Unit III. As regards the stratigraphic sequence it is possible to notice that in Room 10 the eastern and western walls abut on the northern wall, and the embedded pillars in turn abut on the eastern and western walls. The western wall was erected in two main phases: a base of rubble stone and medium-size irregularly shaped stones, above which there is a layer of blocks and empty spaces into which the laying surface could be set; the same layer of stones found both in Room 7 and the mosque is also preserved in the floor of Rooms 10, 11 and 12. In the southwest corner of Room 12 we find a bench composed of square blocks of limestone and basalt, regularly arranged. ${ }^{28}$ The measurements of each room are: Room 8: $3.61 \times 3.54$ m; Room 9: 3.66 × 3.97 m; Room 10: $6.81 \times 8.69$ m; Room 11: $7.42 \times 3.16$ m; Room 12: $7.69 \times 3.51 \mathrm{~m}$; Room 13: $7.23 \times 8.04 \mathrm{~m}$.

\subsubsection{The bath complex}

The bath complex (fig. 6) ${ }^{29}$ consists of six rooms, arranged in two groups: the first is composed of Rooms A and B, which connect the bath complex to the rest of the palace through Room A and to the outside through Room B. The second group is composed of the thermal complex, i.e. an apodyterium (Room C), a laconicum (Room D), a calidarium (Room E) and the praefurnium (Room F).

Room A $(5.15 \times 3.62 \mathrm{~m})$ is connected to the central courtyard of Unit I, the apodyterium and Room B; the pavement is composed of rubble, but it most likely had a coating layer above it. In the northwestern corner we find a pipeline coming from Room $\mathrm{B}$.

Room в $(8.22 \times 4.59 \mathrm{~m})$ shows two semicircular niches: one on the western side, $2.96 \mathrm{~m}$ thick and $2.84 \mathrm{~m}$ deep, with an inner and external semicircular outline; and a second one on the northern side, $1.70 \mathrm{~m}$ thick and $2.15 \mathrm{~m}$ deep, with an inner and external circular outline (the inner one has an elongated shape). Two benches of rubble coated by mortar are found on the western and southeastern sides: the first one measures $8.04 \times 0.40 \mathrm{~m}$, while the second measures $0.71 \times 2.28 \mathrm{~m}$. Room B is connected to Room A and to the exterior through a doorway $0.83 \mathrm{~m}$ wide leading to Unit II (fig. 2). The two benches and the two niches may suggest that this was the audience room of the bath complex, as in other Umayyad examples. Furthermore, in this room the excavators found some painted wall decoration with geometrical and floral patterns. ${ }^{30}$

Room C (apodyterium, fig. 6) is roughly a quadrangular room $(3.46 \times 3.94 \mathrm{~m})$; it has a "U"-shaped bench of rubble coated by mortar. ${ }^{31}$ A pipeline coming from Room A is located in the northeastern corner, where traces of an opus sectile floor were found. This room is connected to Rooms A and D and can be interpreted as the apodyterium of the bath complex due to its location and the bench. This kind of apodyterium is typical of all Umayyad thermal complexes.

28 I would like to thank Professor Alessandro Maria Jaia for discussing this subject with me.

9 al-Husan 2002, 77-79, figs. 7-9.

al-Husan 2002, 79, fig. 10.

31 At present the benches are coated with small new marble slabs. 
Room D (figs. 6-7) is a roughly quadrangular structure $(3.62 \times 3.92 \times 3.55 \times 4.02 \mathrm{~m})$, preserved to a height of ca $1.70 \mathrm{~m}$ and incorporating a circular structure with an irregular profile (diameter ca $2.30 \mathrm{~m}$ ) and a circular seat $(0.36 \mathrm{~m}$ deep and almost $0.40 \mathrm{~cm}$ high). It can suggest a circular floor which was most likely plastered as the floor level of the calidarium is at the same height as the seat level, suggesting that the hypocaustum of the calidarium and Room D were connected. ${ }^{32}$ It is unlikely that the circular space was filled with water due to the absence of hydraulic mortar and a duct in the southern side, the latter being completely open. Two pipelines were located in the room: one coming from the calidarium and traversing the whole room, and another running under the seat on the northern side. This room is connected to the calidarium to the north and the apodyterium to the south. In any case, the connection to the apodyterium leads to some observations: the ground level of the apodyterium is lower than that of Room D; this implies that the two rooms should have been connected by almost two steps, and indeed negative traces of steps were found at the entrance to Room D. But what was the function of the room? The laconicum seems to be infrequent in Umayyad baths but we found a comparison in the baths of al-Barā (Northern Syria) where a room from the Byzantine bath (Room VI) was readapted in Umayyad times, introducing a laconicum. ${ }^{33}$ Looking at the earlier examples, we can suggest a laconicum, that is "a small circular vaulted room heated to a high temperature by a special fire or (...) by a brazier", ${ }^{34}$ close to the heated rooms; the temperature here was "certainly considerable". ${ }^{35}$

Room $\mathrm{E}$ is the calidarium. It is preserved to a height of between 1.70 and $1.90 \mathrm{~m}$, and is a quadrangular room measuring $3.79 \mathrm{~m}$ per side. 35 circular pilae stacks composed of 9 circular bricks (each $0.10 \mathrm{~m}$ in height) and 8 rectangular pilae stacks, two for each corner, are located in the stone layer. ${ }^{36}$ In the middle of the east and west sides there are two rectangular basins $(1.16 \times 0.76 \mathrm{~m})$ : in the eastern one the marble decoration is still in situ. The basins were at the same height as the pavement, that is ca $1 \mathrm{~m}$, and the tracks of the latter are noticeable in the inner walls. The hypocaust is connected to the praefurnium (Room F) through a narrow tunnel, composed of bricks. Room $\mathrm{F}$ is a rectangular room (6.13 $\times 4.17 \mathrm{~m}$ ) and presents a single entrance on the east side, ${ }^{37}$ connecting this room to the outside.

Furthermore, Jordanian archaeologists found a pipeline oriented E-NW / S-SW towards the wādī al-Fudayn. ${ }^{38}$

\footnotetext{
The floor was likely supported by pilae which have not survived to the present day.

Charpentier 2014, 478-479, fig. 16; the diameter of the circular structure at al-Barā is ca $1.20 \mathrm{~m}$.

Adam 2005, 568, fig. 636.6.

Adam 2005, 568, fig. 636.6; this type of room in the Umayyad baths requires a more detailed study.

al-Husan 2002, 77-79, figs. 8-9.

al-Husan 2002, 77-79, figs. 8-9.

The logline has been included in the plan published by Jordanian archaeologists (al-Husan 2001, fig. 7); I would like to thank Professor Alessandro Maria Jaia for discussing this subject with me.
} 


\subsubsection{Unit II}

Unit II (fig. 8) is an almost quadrangular building $(19.53 \times 20.13 \mathrm{~m})$, ca $15 \mathrm{~m}$ east of Unit I. The building shows a central courtyard with nine rooms surrounding it and an entrance on the north side. It occupies an area of $216.93 \mathrm{~m}^{2}$.

Rooms $1(5.88 \times 3.72 \mathrm{~m})$ and $2(6.35 \times 3.74 \mathrm{~m})$ are located respectively to the east and west of the vestibule. These rooms could only be accessed through the vestibule $(2.87 \times 5 \mathrm{~m})$.

Rooms $3(3.95 \times 2.78 \mathrm{~m})$ and $4(3.94 \times 3.04 \mathrm{~m})$, and Rooms $8(3.47 \times 3.01 \mathrm{~m})$ and 9 $(3.93 \times 3.25 \mathrm{~m})$ display a similar plan and are only connected to the central courtyard.

Rooms $5(5.80 \times 4 \mathrm{~m})$ and $7(5.72 \times 3.97 \mathrm{~m})$ are in the southern corners of the building.

Room 6 (3.12 $\times 3.61 \mathrm{~m})$, to the south, is located in line with the entrance.

The central courtyard $(7.67 \times 6.99 \mathrm{~m})$ presents a pit. On the northern side we find two staircases opposite each other leading to a second floor which is now missing. Five steps are preserved for the eastern flight, and four for the western one.

The average thickness of the external wall is ca $1.50 \mathrm{~m}$; that of the inner wall is ca $1 \mathrm{~m}$. The entire complex is paved with stone slabs. Concerning the construction technique, the inner dividing walls abut on the external perimeter.

The building can be compared to other extra-urban residences of the Umayyad period showing similar dimensions and also devoid of towers, such as House A of Qașr al-Hayr alSharqī, ${ }^{39}$ Qașr al-Mshash and Qașr 'Ayn al-Sil, ${ }^{40}$ the residence at Qușayr 'Amra and Building E of Jabal al-Says. ${ }^{41}$

\subsubsection{Unit III}

Unit III (fig. 2) corresponds to the western terrace; it is mostly unexcavated and occupies an area of $70 \times 46 \mathrm{~m}$. The entrance is on the eastern side through a narrow passageway (width $1.20 \mathrm{~m}$ ) that reused the vestibule of the Byzantine complex; the threshold of the door was covered by a «beau sol plâtré sur un mortier épais». ${ }^{42}$ The complex displays a central courtyard $(27.5 \times 47.3 \mathrm{~m})$ with surrounding rooms; French archaeologists indicated the presence of a portico, dated to the Byzantine period. On the northeastern side we find a chapel $(8.3 \times 14.7 \mathrm{~m})$ with three naves spaced out by piers $(1 \mathrm{~m}$ per side), ending with a single apse; the church is oriented E-W and the floor is a stone mosaic composed of white, red and black tesserae; in the central nave the mosaic shows a lozenge pattern and a framed Greek inscription, ${ }^{43}$ stating:

+ EK [----?---- $]$

----ca 2-3---- [X][----?----]

----ca 2-3---- (Y)A [----?----]

----ca 2-3----O(П)[O] [----?----]

$\Gamma(\mathrm{IT})[---?---]$

39 Genequand 2012, 110-115, figs. 89-97.

40 Bisheh 1989, 83-84, 90-91, pls. 2.a, 6.

41 Genequand 2012, 204, figs. 212-213.

42 Humbert 1986, 356.

43 Bisheh et al. 2010, figure at page 133; I would like to thank Ioanna Arvanitidou, Professor Yota Atzaka Aristotle University of Thessaloniki - and Anastasia N. Gkiogki for their help in reading the inscription. 
Between Unit III and Unit I we find an enclosure, most likely a court, but its original function, the chronology and the location of the entrance have been ignored.

\subsection{The construction techniques of the Umayyad period of al-Fudayn}

The construction techniques of the buildings were those widely employed in the region in the same period, that is walls with a rubble masonry core and a cladding of squared blocks in the doorjamb (but not in the corners of the rooms) and irregularly shaped blocks with wedging to establish the laying surface. The blocks are mainly of local limestone, although some basalt blocks were used. ${ }^{44}$ Furthermore, we note the select use of baked bricks in the calidarium and in the praefurnium of the bath complex in relation to the heating system.

As regards the decoration, stucco was found in the mosque and marble in the bath complex (slabs and opus sectile pavement).

\subsection{The stucco decoration of the qiblī wall}

The qibli $\bar{\imath}$ wall of the mosque shows a stucco ornament discovered in situ by Jordanian archaeologists (fig. 9). The wall section to the left of the mihrāb is $1 \mathrm{~m}$ long, while the eastern section is $2.73 \mathrm{~m}$. The original decoration is preserved in the lower part of the eastern wall, for a height of $0.74 \mathrm{~m}$ and length of $1.64 \mathrm{~m}$ (corresponding to the length of the eastern side of the wall); in the eastern corner of the wall to the left of the mihrāb; on the bases of the englobed columns and on the embedded pillars; and finally, on the lower part of the mihrāa decoration. Moreover, an integrative restoration of the qibli wall was carried out by Jordanian team. ${ }^{45}$

\subsubsection{Description of the stucco decoration}

The carved and incised stucco decoration of the qibli wall (fig. 10) is composed of interlaced geometrical and vegetal patterns. The decoration has a central rectangular panel decorated with interlaced "swastikas" alternating with six-petal rosettes (fig. 11a), framed by a chevron pattern and an outer frame of guilloches.

The upper decoration is less preserved, but it has been reconstructed as follows by Jordanian archaeologists thanks to the fragments found during the excavations: ${ }^{46}$ up to the guilloche frame there was a frieze of interlocking chevron patterns (fig. 12a) and, above this, a continuous strip of palmettes with seven petals (fig. 12b); each palmette shows incised and grooved rounded lobes. The height of the interlocking chevron pattern is 0.05 $\mathrm{m}$; the frieze of palmettes is $0.19 \mathrm{~m}$ high.

The decoration of both the embedded pillars (fig. 12c) is preserved only on the lower part and consists of a socle (height $0.20 \mathrm{~m}$ ), above which there is a single trefoil facing left. The englobed columns of the mihrā $b$ are encrusted with a plaster revetment carved with a scales pattern.

44 The basalt is a typical material of the southern Hawrān.

45 al-Husan 2002, 76-77, figs. 5-6.

46 See al-Husan 2002, fig. 7. 
The decoration of the mihrāa niche is preserved only in its lower part, showing a strip of roundels enclosing rosettes.

\subsubsection{Comparisons with the Umayyad examples (tab. 1)}

The stucco decoration of al-Fudayn clearly belongs to the decorative tradition of the Umayyad period; ${ }^{47}$ in fact, there are several comparisons with this tradition, ${ }^{48}$ which are schematically listed below:

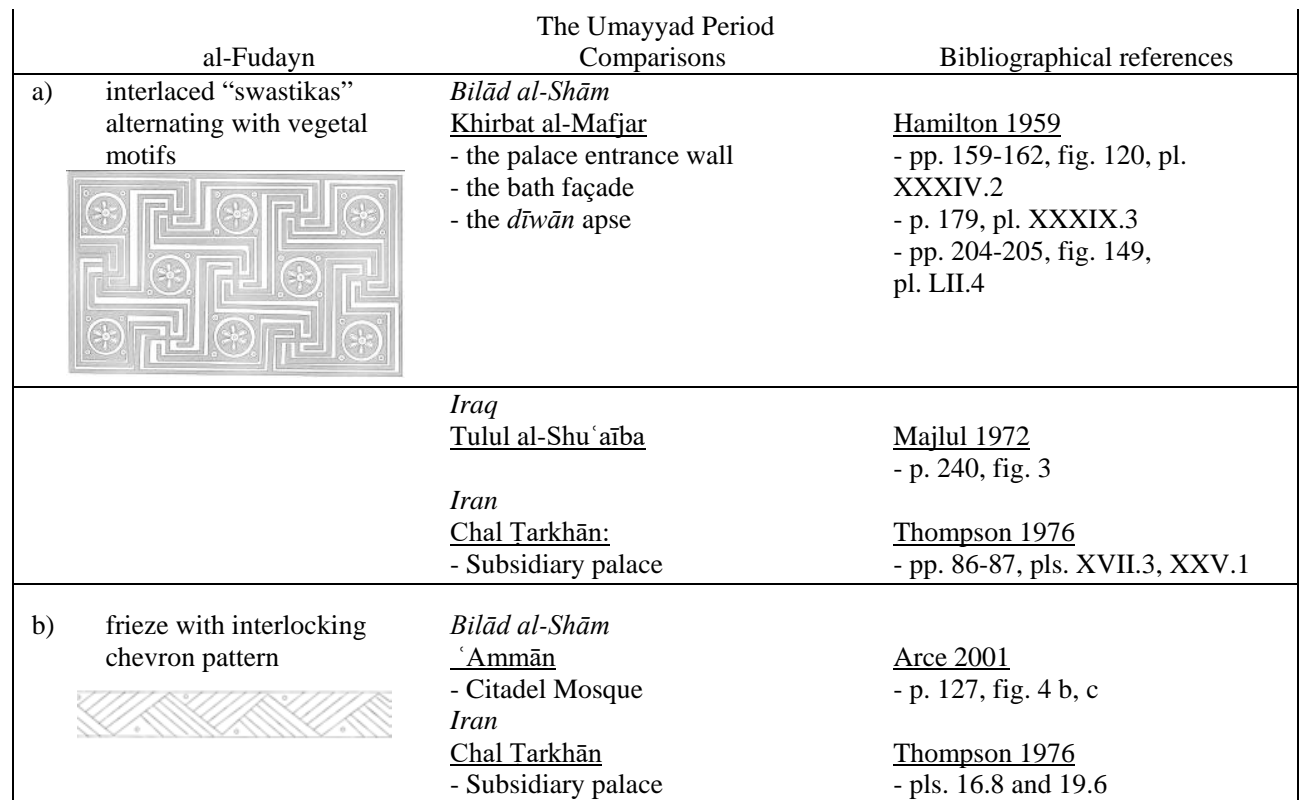

47 According to Anna Ballian the stucco decoration dates to the early Abbasid period (Ballian 2012, 212), but I suggest an Umayyad dating because the decoration has precise comparisons with the decoration of other Umayyad complexes (see below); in fact the early Abbasid decoration shows different patterns: see, for example, in the Bilād al-Shām the stuccoes of al-Raqqa dated to the reign of Harūn al-Rashīd (786-809; Meinecke 1991); in Iran the stuccoes of the first Masjid-i Jum'a of Ișfahān dated precisely to 156/772-73 (Scerrato 2014, 661-672, figs. 6-10), those of Susa dated to the second half of the $8^{\text {th }}$ century (Hardy-Guilbert 1990, 269-275, figs. 1-3) and the recently discovered stuccoes at Darra Shahr, $8^{\text {th }}$ century (Elam; Lakpour 1389/2011); in the Arabian Peninsula the stucco decoration at al- 'Alwiyāh dates to the early $9^{\text {th }}$ century (see Meineke 1991, 229-230, fig. 12).

48 Firstly the stucco motifs of the Umayyad period are compared, and afterwards those of the Sasanian and Nabataean periods; guilloches, trefoils, vegetal roundels and palmette friezes are not included in the tables because these motifs are too widely used. 
englobed columns of the $m i \grave{h} r \bar{a} b$

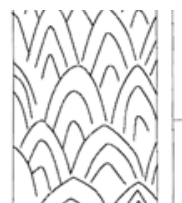

Bilād al-Shām

Qașr al-Hayr al-Gharbī $\quad \underline{\text { Schlumberger } 1986}$

- southern façade of the palace - pp. 15-16, pl. 63.e

Iran

- Darra Shahr, mosque - Lakpour 1389/2011

- figs. 95.b-c, pls. 113-114

Tab. 1 - Comparisons with the Umayyad examples.

Apparently, the chevron-patterned frame has no comparison with the Umayyad stucco decoration; in any case, some comparisons can be traced in the Tulul al-Ukhaydīir stuccoes. ${ }^{49}$ Furthermore, it can be supposed that the Kunstwollen here was a reproduction of the marble veins ${ }^{50}$ on a stucco support, which is noticeable, for example, in the wall paintings of Qușayr 'Amra ${ }^{51}$ and al-Rușāfa. ${ }^{52}$

\subsubsection{Origins of the patterns (tab. 2)}

The patterns of the stucco decoration of the qibli wall derive from Sasanian and Nabataean motifs. Here is a list of the main comparisons:

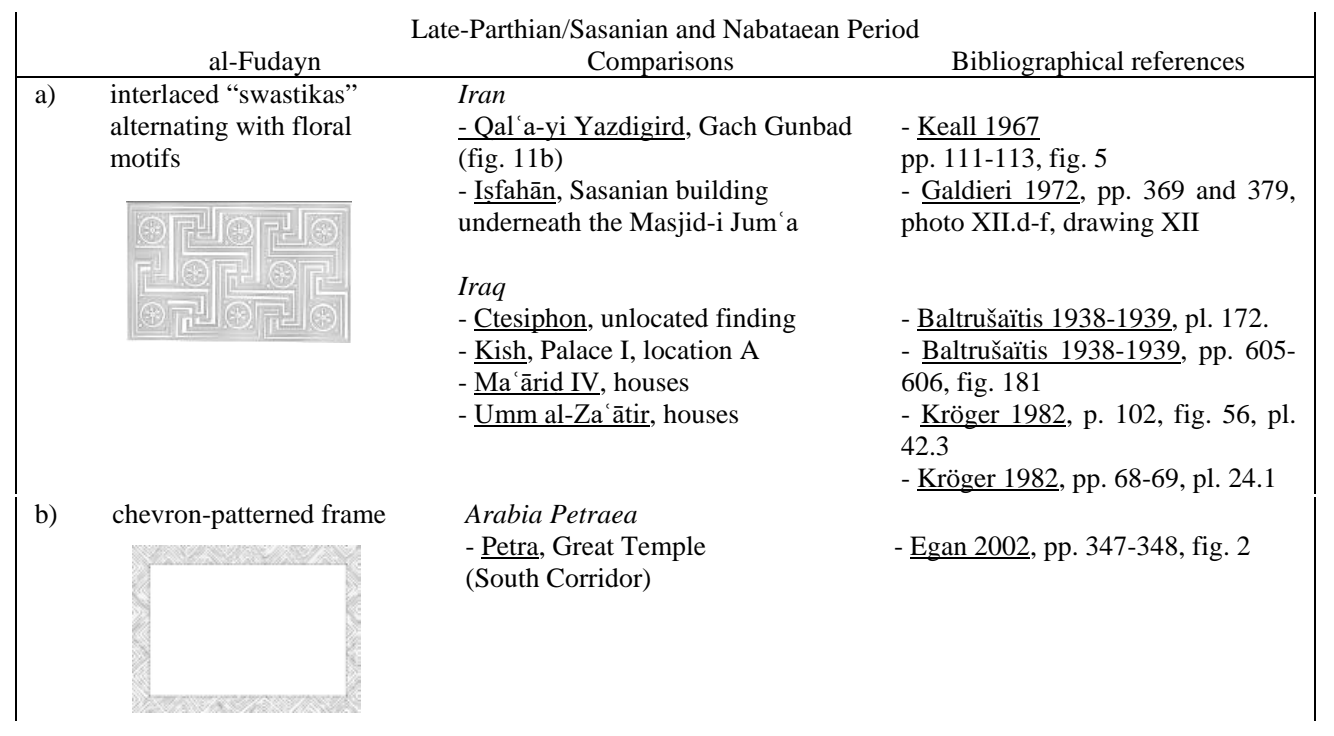

49 Finster - Schmidt 1976, 84, pls. 44-45.

50 Such as the veins of the marble decoration in the Dome of the Rock (Creswell 1979, pl. 4b; Rosen-Ayalon 1989, fig. 27), the Umayyad Mosque of Damascus (Creswell 1979, pl. 47) and the reconstruction of the marble decoration in the Medina mosque during the Umayyad phase (Sauvaget 1947, 78-80, fig. 3).

51 Vibert-Guigue - Bisheh 2007, pls. 22.a, 23.a, 24.a, 25.c, 26, 29, 31, 34, 85, 114.a, 118, 122.b, 130.e.

52 Otto-Dorn 1957, 125, fig. 7. 


\begin{tabular}{|c|c|c|c|}
\hline \multirow[t]{2}{*}{ c) } & $\begin{array}{l}\text { frieze with interlocking } \\
\text { chevron pattern }\end{array}$ & $\begin{array}{l}\text { Iran } \\
\text { - Nizāāmābād }\end{array}$ & - Kröger 1982, pp. 149-150, pl. \\
\hline & & $\begin{array}{l}\text { Iraq } \\
\text { - Umm al-Za ātir, houses } \\
\text { - } \text { Ma ārid IV, houses }\end{array}$ & $\begin{array}{l}\text { - Kröger 1982, pp. 63-64, fig. 28.j, } \\
\text { pl. } 15.3 \\
\text { - Kröger 1982, p. 94, pl. } 36.3\end{array}$ \\
\hline e) & $\begin{array}{l}\text { englobed columns of the } \\
\text { mihrāab }\end{array}$ & $\begin{array}{l}\text { Iraq } \\
\text { - Ctesiphon, unlocated finding } \\
\text { - } \text { Ctesiphon, Church } \\
\text { - } \underline{\text { Kish, Palace I }} \\
\text { - Ma āriḍ IV, houses }\end{array}$ & $\begin{array}{l}\text { - Kröger 1982, pl. 54.3 } \\
\text { - Kröger 1982, p. 46, pl. } 12.4 \\
\text { - Watelin 1938-1939, fig. 171.b; } \\
\text { Baltrušaïtis 1938-1939, p. 602, fig. } \\
172 \text { a-d } \\
\text { - Kröger 1982, fig. 28.k-l, pl. 36.4- } \\
\text { 5 }\end{array}$ \\
\hline
\end{tabular}

Tab. 2 - Origins of the patterns.

\section{CONCLUSIONS AND DATING}

The site of al-Fudayn belongs to the «établissement résidentiel développé» ${ }^{53}$ typology of the Umayyad period; it shows some distinctive characteristics in the bath complex and the stucco decoration of the qibli wall. But what is the dating of the complex?

Considering that two daughters of Sa'̄̄d ibn Khālid ibn 'Amr ibn 'Uthmān ibn 'Affān (the owner of the site) were married to the Umayyad Caliphs Hishām ibn 'Abd al-Malik (724-743) and al-Walīd ibn Yazīd (743-744), the terminus post quem for the complex is ca 744, while the terminus ante quem remains uncertain, but it can be ascribed to between the first and the second quarter of the $8^{\text {th }}$ century.

As far as we know the stucco decoration of the qibli wall is the unique stucco decoration of a qibli wall from the Umayyad period which can be completely reconstructed: here we notice the use of patterns typical of the pre-Islamic Iranian tradition, likely to be found in other Umayyad contexts. Furthermore, the chevron motif is usefully comparable to the decoration of an important Nabataean site, namely Petra.

The hammām of al-Fudayn plays a quite exceptional role in the panorama of the Umayyad baths, in terms of the laconicum and the audience hall (Room B). The audience hall model observed here finds no comparisons with that of baths of the same period: its distinctiveness is in the two niches facing the benches.

As regards the laconicum it is infrequently used in the Umayyad baths and deserves a more detailed analysis and comparisons.

53 Genequand 2012, 236. 


\section{REFERENCES}

ADAM, J.-P.

2005 Roman Building. Materials and Techniques, London - New York 2005.

AlMagro, A. - JiMÉNEZ, P.

2000 The Umayyad Mosque in the Citadel of Amman: Annual of the Department of Antiquities of Jordan 44 (2000), pp. 459-475.

Almagro, A. - JimÉnEZ, P. - NAVARRo, J.

2000 El Palacio Omeya de Amman, III. Investigación Arqueologica y Restauración 1989-1997, Granada 2000.

ARCE, I.

2001 The Umayyad Carved Stucco from Amman Citadel Congregational Mosque: in G. Biscontin- G. DRIUSSi (eds.), Lo stucco. Cultura, tecnologia, conoscenza (Scienza e Beni Culturali XVII), Atti del convegno di studi (Bressanone 10-13 luglio 2001), Venezia 2001, pp. 125-140.

BALLIAN, A.

2012 al-Fudayn: H.C. EvANS - B. RATLIFF (eds.), Byzantium and Islam. Age of Transition (7th 9th Century), New York 2012, pp. 212-216.

BALTRUŠAÏTIS, J.

1938-1939 Sāsānian Stucco. A. Ornamental: A.U. PoPE - P. ACKerman (eds.), A Survey of Persian Art from Prehistoric Times to the Present, London - New York 1938-1939, pp. 601-630.

BISHEH, G.

1989 Qasr Mshash and Qasr 'Ayn al-Sil: Two Umayyad Sites in Jordan: A.M. BAKHIT - R. SCHICK (eds.), The Fourth International Conference on the History of Bilād al-Shām during the Umayyad Period: Proceedings of the third symposium, 'Ammān 1989, pp. 81103.

2015 Fudayn: Discover Islamic Art. Place: Museum With No Frontiers, 2015 (http://www.discoverislamicart.org/database_item.php?id=monument;ISL;jo;Mon01;6;en)

BisheH, G. - ZAYAdine, F. - AL-AsAd, M. - KeHRBERG, I. - TOHME, L.

2010 The Umayyads. The Rise of Islamic Art, Vienna 2010.

CHARPENTIER, G.

2014 Les bains d'al-Bāra (2008-2010): M.-F. BoussaC - S. Denoix - T. Fournet - B. Redon (eds.), 25 siècles de bain collectif en Orient. Proche-Orient, Égypte et péninsule Arabique (Actes du $3^{\mathrm{e}}$ colloque international Balnéorient; Coédition Ifao, Études urbaines 9 - Ifpo, Publications de l’Institut Français de Damas 282), Cairo 2014, pp. 465-493.

Creswell, K.A.C.

1979 Early Muslim Architecture, New York 1979 (reprint of the $2^{\text {nd }}$ edition of 1969).

EGAN, E.C.

2002 Stucco Decoration from the South Corridor of the Petra Great Temple: Discussion and Interpretation: Annual of the Department of Antiquities of Jordan 46 (2002), pp. 347-361.

FINSTER, B. - SCHMIDT, J.

1976 Sasanidische und Frühislamische Ruinen im Iraq (Baghdader Mitteilungen 8), Berlin 1976.

GALDIERI, E

1972 Ișfahān: Masğid-i Ğum ‘a, 1, Roma 1972.

GENEQUAND, D.

2012 Les établissements des élites omeyyades en Palmyrène et au Proche-Orient, Beyruth 2012. 
GLUECK, N.

1942 Further Explorations in Eastern Palestine: Bulletin of the American Schools of Oriental Research 86 (1942), pp. 14-24.

1945-1949 Explorations in Eastern Palestine, IV. Part I: Text: The Annual of the American Schools of Oriental Research 25/28 (1945-1949), pp. iii, v, vii, ix-xix and 1-423.

GRABAR, O.

1964 A Small Episode of Early Abbasid Times and Some Consequences: Eretz Israel 11 (1964), pp. 44-47.

HAMILTON, R.

$1959 \quad$ Khirbat al-Mafjar. An Arabian Mansion in the Jordan Valley, Oxford 1959.

HARDY-GUILBERT, C.

1990 Stucs islamiques de Suse: F. Vallat (ed.), Contribution à l'histoire de l'Iran. Mélanges offerts à Jean Perrot, Paris 1990, pp. 269-293.

HUMBERT, J.-B.

1986 El-Fedein/Mafraq: Liber Annuus 36 (1986), pp. 354-358.

1989 El-Fedein/Mafraq: F. Villentuve (ed.), Contribution française à l'archéologie jordanienne, Amman 1989, pp. 125-131.

AL-HusAn, A.-Q.

2001 Preliminary Results of the Archaeological Excavations at Al-Mafraq 1991-2001: Annual of the Department of Antiquities of Jordan 45 (2001), pp. 5-13 (Arabic Section).

2002 The New Archaeological Discoveries of the al-Fudayn and Rahāb - al-Mafraq Excavation Projects, 1991-2001: Annual of the Department of Antiquities of Jordan 46 (2002), pp. 71-94 (Arabic Section).

KEALL, E.J.

1967 Qal'eh-i Yazdigird: A Sasanian Palace Stronghold in Persian Kurdistan: Iran 5 (1967), pp. 99-121.

KENNEDY, D. - BEWLEY, R.

2004 Ancient Jordan from the Air, London 2004.

KENNEDY, D. - AL-HusAn, A.G.

1996 New Milestones from Northern Jordan: 1992-1995: Zeitschrift für Papyrologie und KRÖGER, J. Epigraphik 113 (1996), pp. 257-262.

$1982 \quad$ Sasanidischer Stuckdekor (Baghdader Forschungen 5), Mainz am Rhein 1982.

LAKPOUR, S.

1389/2011 Archaeological Excavations and Researches of Darreh Shahr (Saymareh), Elam 1389 [2011] (in Persian).

MAJLUL, D.

1972 Telul esh Sheibah: Sumer XXVIII/1-2 (1972), pp. 243-246 (Arabic section).

MEINECKE, M.

1991 Early Abbasid Stucco Decoration in Bilād al-Shām: M. A. AL-BAKHIT- R. Schick (eds.), Bilād al-Shām during the Abbasìd Period (132 A.H. / 750 A.D. - 451 A.H. / 1059 A.D.), Proceedings of the Fifth International Conference on the History of the Bilād al-Shäm, 'Ammān 1412 A.H. / 1991 A.D., pp. 226-267.

OTTO-DORN, K.

1957 Grabung im Umayyadischen Rușāfah: Ars Orientalis 2 (1957), pp. 119-133.

ROSEN-AyALON, M.

1989 Early Islamic Monuments of al-Haram al-Sharïf. An Iconographic Study (Qedem 28), Jerusalem 1989. 
SAPIN, J.

1998 À l'est de Gerasa. Aménagement rural et reseau de communications: Syria 75 (1998), pp. 107-136.

SAUVAGET, J.

1947 La mosquée omeyyade de Médine. Étude sur les origines architecturales de la mosquée et de la basilique, Paris 1947.

SCERRATO, U.

2001 Ricerche archeologiche nella moschea del Venerdì di Isfahan della Missione archeologica Italiana in Iran dell'IsMEO (1972-1978): Antica Persia. I tesori del Museo Nazionale di Tehran e la ricerca italiana in Iran, Exhibition Catalogue, Museo Nazionale d'Arte Orientale (Roma, Palazzo Brancaccio, 29 maggio-22 luglio 2001), pp. XXXVI-XLIII. Roma 2001.

SCHLUMBERGER, D.

1986 Qasr al-Heyr al-Gharbi, Paris 1986.

THOMPSON, D.

$1976 \quad$ Stucco From Chal Tarkhan-Eshqabad near Rayy, Warminster 1976.

Vibert-Guigue, C. - BisheH, G.

2007 Les Peintures de Qusayr 'Amra. Un bain omeyyade dans la bādiya jordanienne, Beyrouth 2007.

WATELIN, L.C.

1938-1939 The Sāsānian Buildings near Kish: A.U. PoPE - P. ACKERMAn (eds.), A Survey of Persian Art from Prehistoric Times to the Present, London - New York 1938-1939, pp. 584-592.

YĀQŪT

1866-1870 Kitāb al-buldān (ed. F. Wünstenfeld), Leipzig 1866-1870.

ŽNIDAREC, J.

2014 La moschea palatina e la cappella palatina: un confronto (secoli IV-IX), MA Thesis, Sapienza University of Rome 2014 (unpublished). 


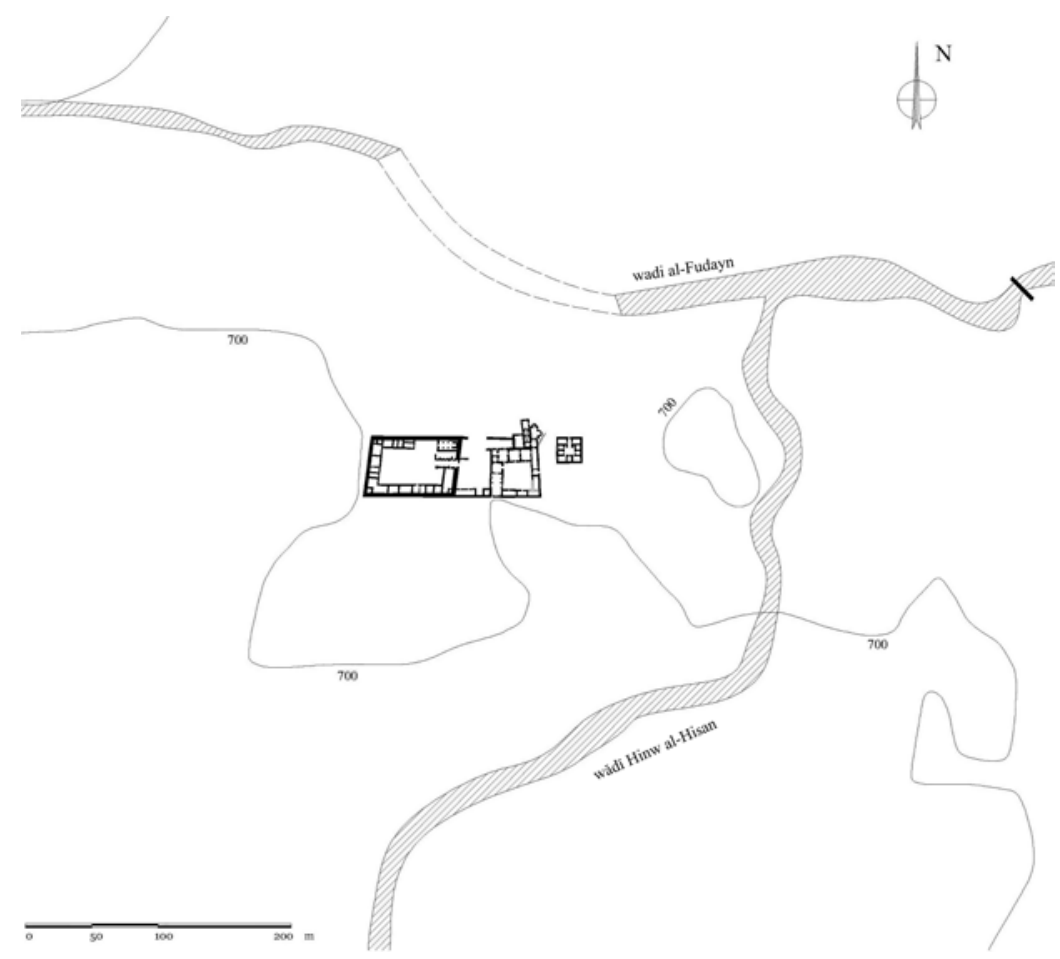

Fig. 1 - The site of al-Fudayn in relation to the wādīs and the barrage (to the northeast; after Google Maps (C).

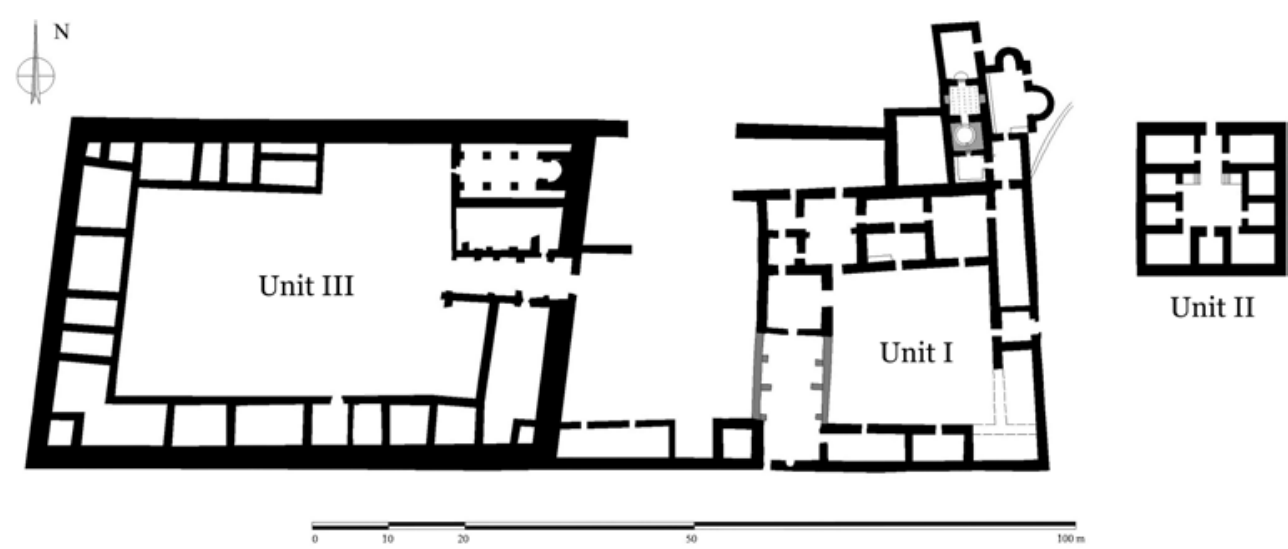

Fig. 2 - Plan of al-Fudayn in the Umayyad phase (after Humbert 1989, figure at page 123; al-Husan 2001, figs. 6-7; 2002, fig. 4; Kennedy - Bewley 2004, fig. 12.9; Bisheh et al. 2010, figure at page 133; Genequand 2012, fig. 216). 


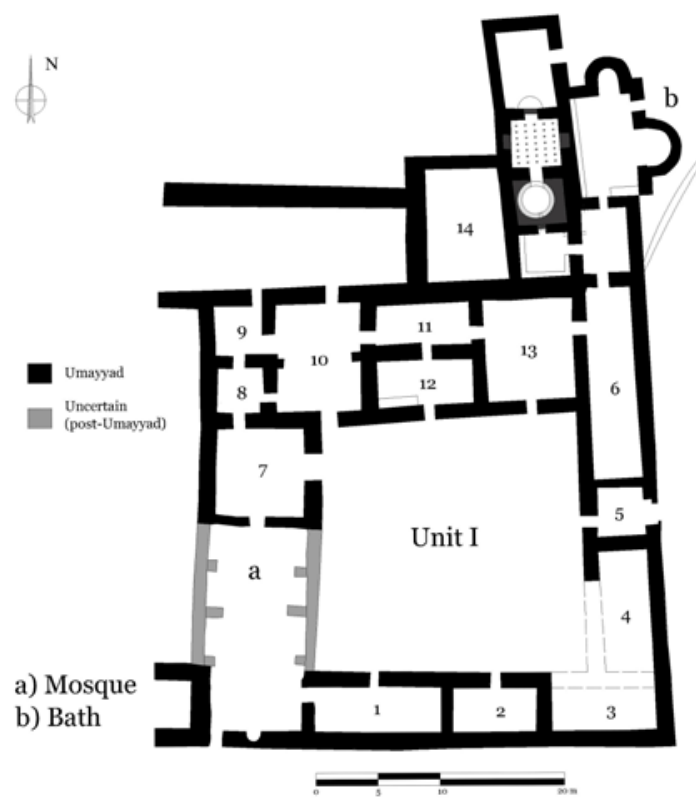

Fig. 3 - Plan of Unit I (after Genequand 2012, fig. 216; al-Husan 2001, figs. 6-7).

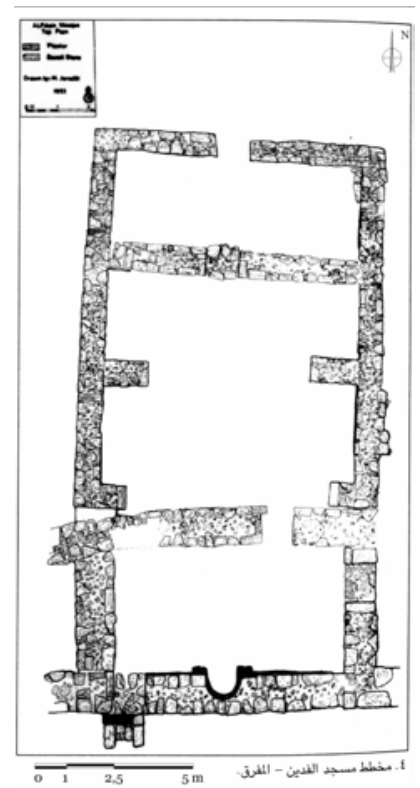

Fig. 4 - Plan of the mosque (all phases are undistinguished; after al-Husan 2002, fig. 4). 


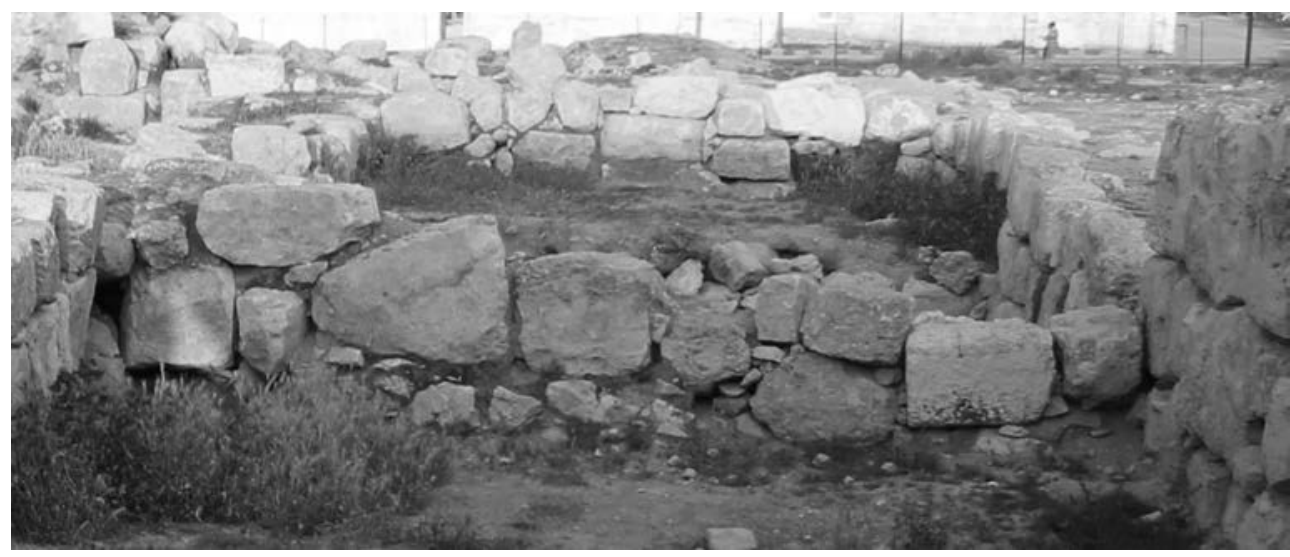

Fig. 5 - Phase IV: detail of the partition wall (ㄷ G. Labisi).

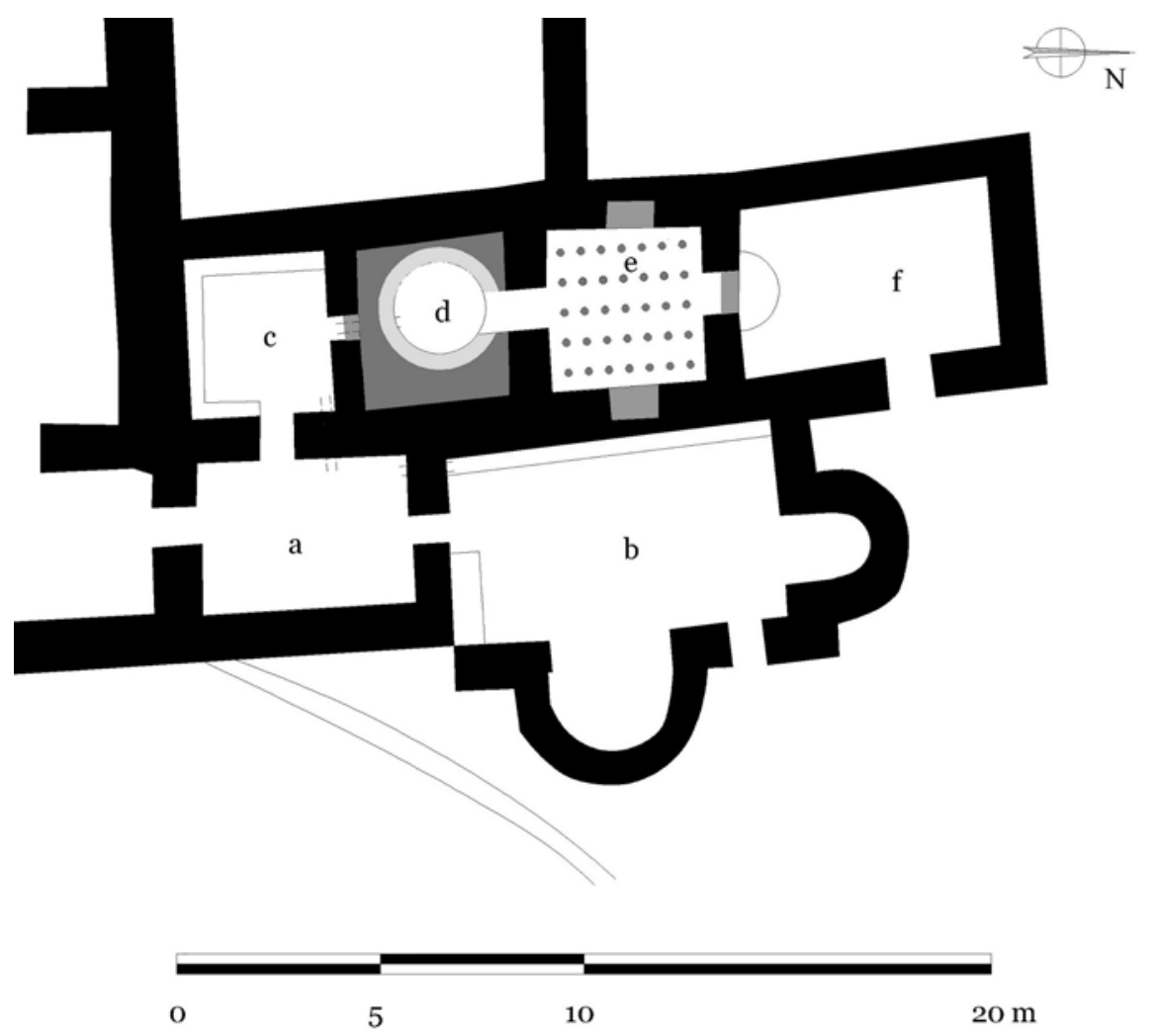

Fig. 6 - Plan of the bath complex (after Genequand 2012, fig. 216 and al-Husan 2001, figs. 6-7). 


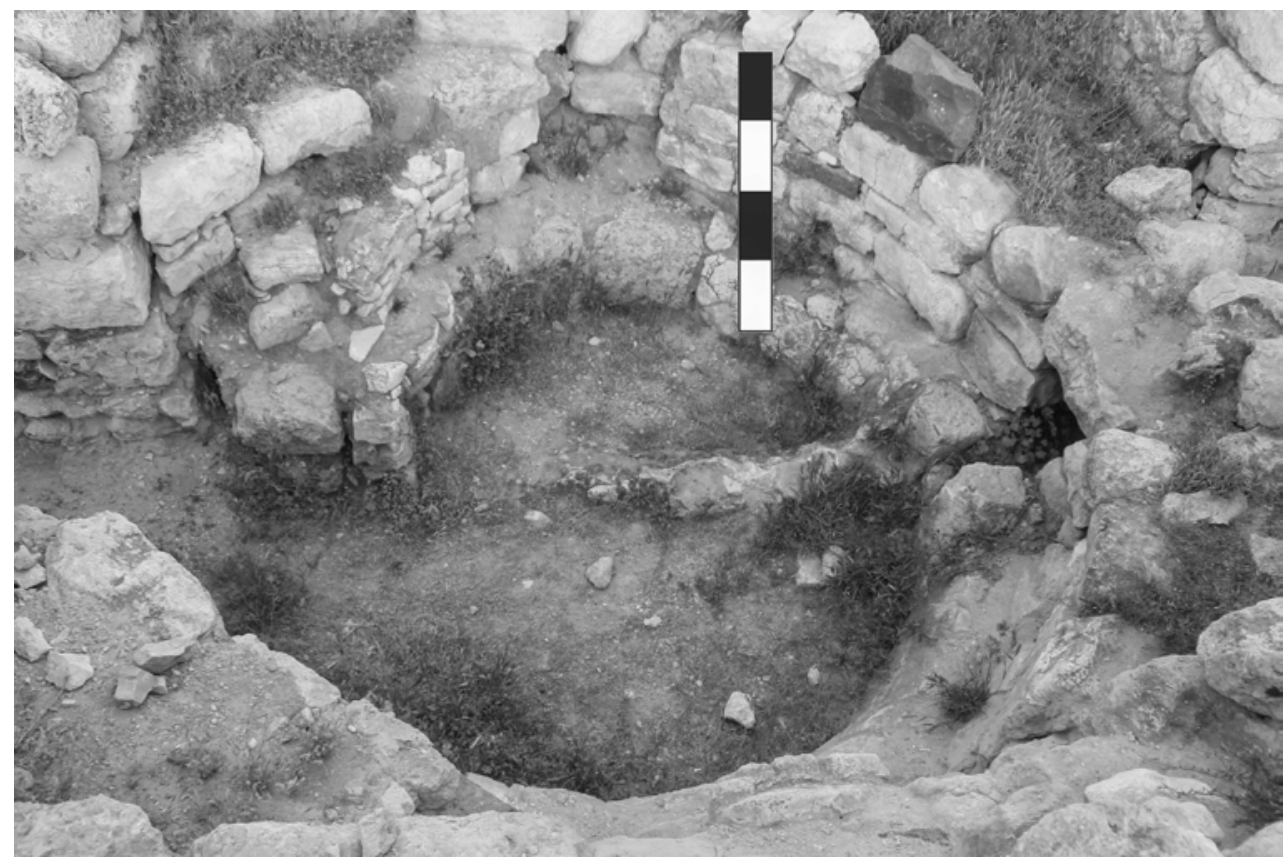

Fig. 7 - Room D (laconicum) of the bath complex (scale 1:40 cm; (C) G. Labisi).

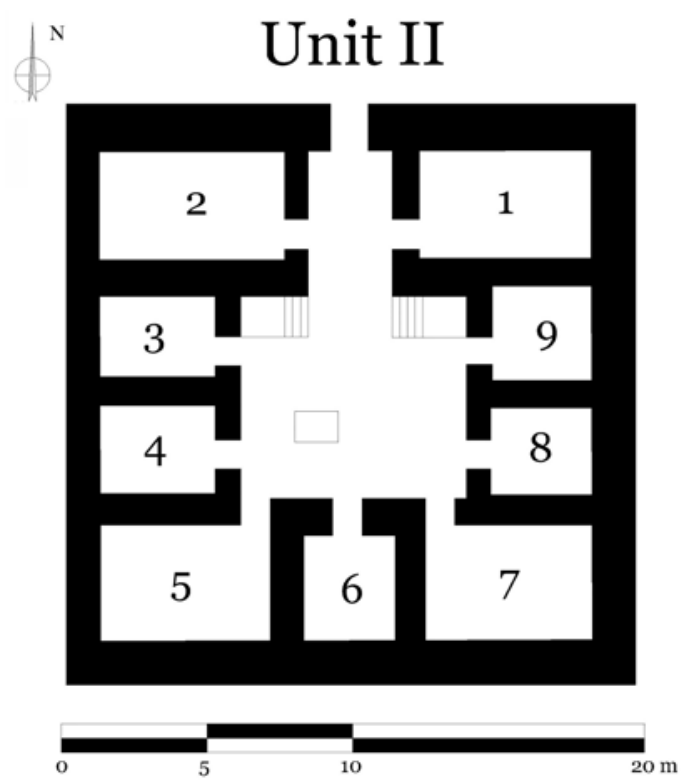

Fig. 8 - Plan of Unit II (C G. Labisi). 


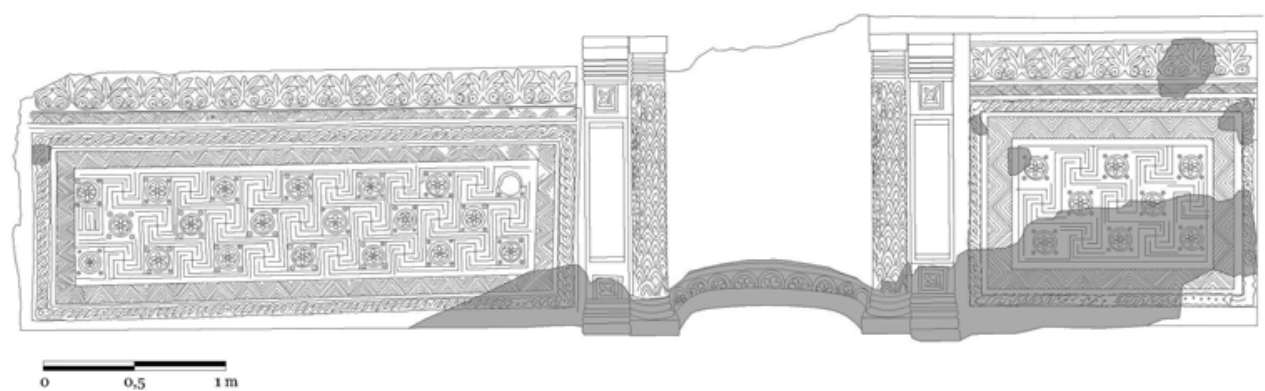

Fig. 9 - al-Fudayn: reconstruction of the qibli wall: the original stucco decoration is shown in dark grey (@ G. Labisi).

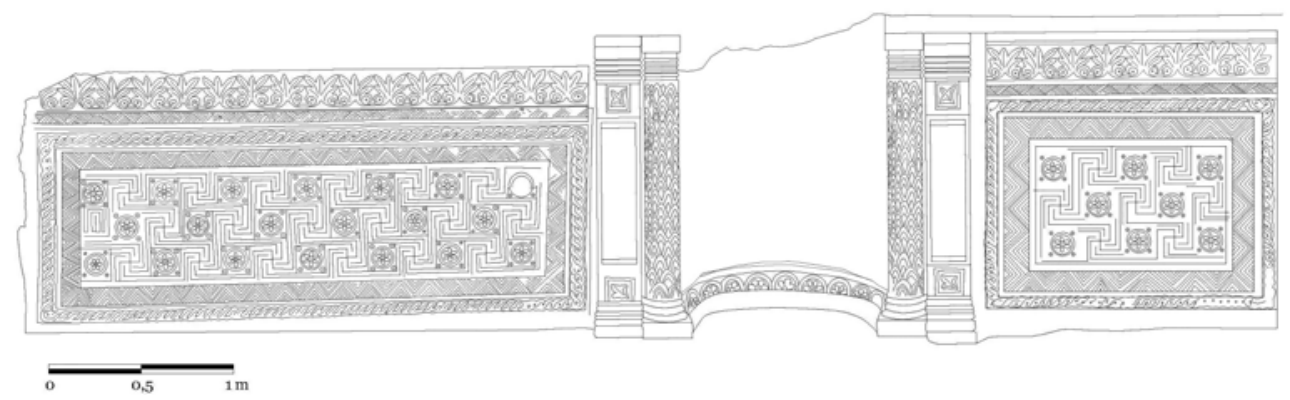

Fig. 10 - al-Fudayn: reconstruction of the qiblī wall ( G. Labisi).

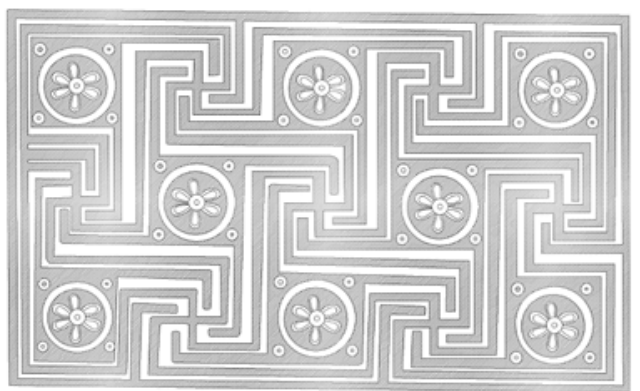

a

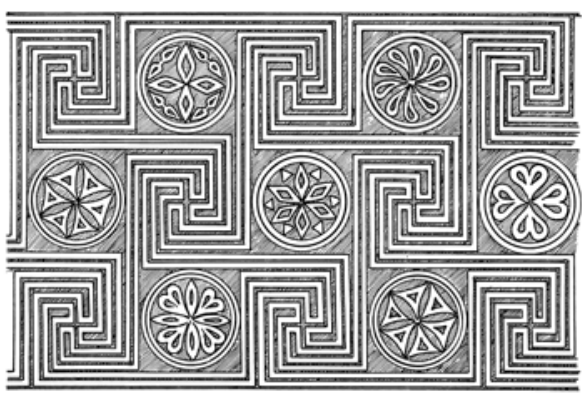

b

Fig. 11 - a) al-Fudayn: detail of the stucco decoration of the qibli wall: interlaced "swastikas" alternating with floral motifs (after al-Husan 2002, fig. 5); b) Qal'a-yi Yazdigird, Gach Gunbad: the stucco decoration (after Keall 1967, fig. 5). 

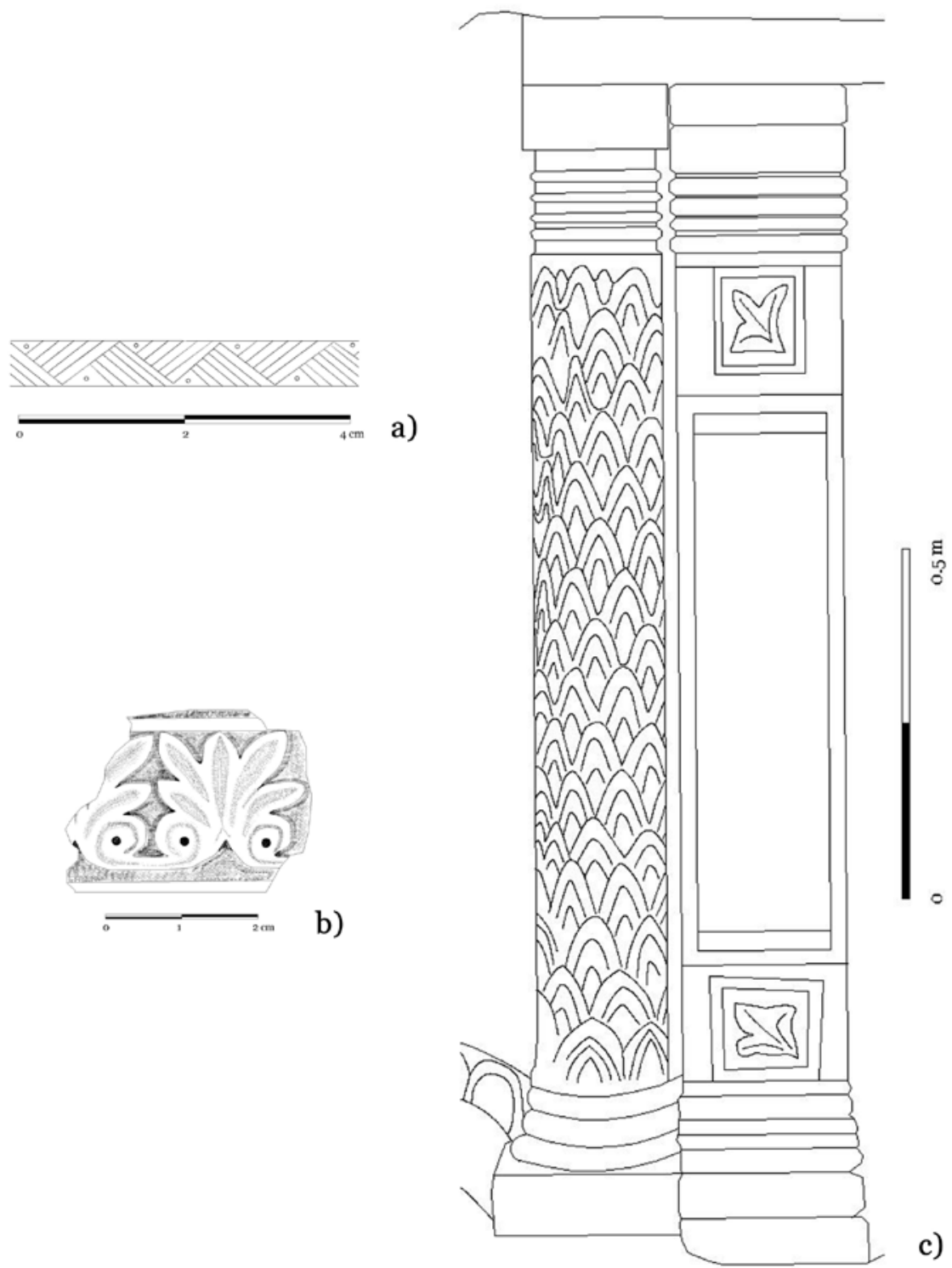

Fig. 12 - al-Fudayn, qiblī wall, stucco decoration: a) Detail: frieze with interlocking chevron pattern (after al-Husan 2002, fig. 5); b) Detail: the palmettes pattern (C G. Labisi); c) Detail: the englobed columns and embedded pillar of the mihrāa (@ G. Labisi). 


\section{SOMMARIO}

DipartimENTo SCIENZE DELl'ANTICHITÀ

SEZIONE di ORIENTALISTICA

\section{VICINO ORIENTE \\ XIX - 2015}

L. Nigro - Bethlehem in the Bronze and lron Ages
in the light of recent discoveries by the Palestinian MOTA-DACH

$\checkmark$. Pisaniello - Parallel passages among Hittite-Luwian rituals:

for the restoration of $K U B 35.146$

F. Spagnoli - Una testa di sileno in bronzo da Mozia

N. Chiaren

dall Area sacra del Kothon a Mozia

G. Labisi - al-Fudayn: an Umayyad residence in Northern Jordan

P. Buzi - Early Christianity in the Fayyūm: the new contribution of archaeology

I. Materia - Preliminary notes on the ware depicted on the ceiling

of the Cappella Palatina in Palermo

S. Autiero - Indian Ocean trade:

a reassessment of the pottery find
$\left(3^{\text {rd }}\right.$ century $B C-S^{S^{t h}}$ century $\left.A D\right)$

M.M. Jamhawi - N. Al-Shakarchi - I. Al-Hashimi

Assessment of tourists' satisfaction in the downtown of Amman

SCAVI E RICERCHE

L. Nigro - C. Fiaccavento - M. Jaradat - J. Yasine

A

L. Nigro - D. Montanari - M. Ghayyada - J. Yasine

A Middle Bronze and Iron Age necropolis near Bethlehem (Palestine)

L. Nigro - G. Ripepi - I. Hamdan - J. Yasine

15 Interim Report

and valorization of archaeological heritage

R. Francia - L'archivio di tavolette del complesso B-C-H di Büyükkale

organizazione degli archivi reali ittiti. Considerazioni preliminari

V. Pisaniello - La collezione di tavolette del complesso B-C-H di Büyükkale

T. De Vincenzi - L'archivio di tavolette del complesso B-C-H
sull'acropoli di Büyükkale

Museo del Vicino Oriente, Egitto e Mediterraneo

L. Nigro - Il nuovo allestimento del Museo del Vicino Oriente,

Egitto e Mediterraneo della Sapienza

D. Montanari - Bollettino delle attività del Museo del Vicino Oriente,

Egito e Meditraneo della Sapienza, anno 2015

RECENSIONI

A. Orsingher - E. PAPPA (2013), Early Iron Age Exchange in the West:

(Ancient Near Eastern Studies Supplement Series 43)

Leuven - Paris - Walpole 2013, MA.: Peeters $\frac{1}{2}$

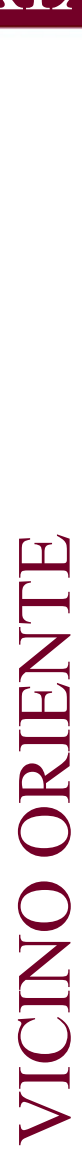

345

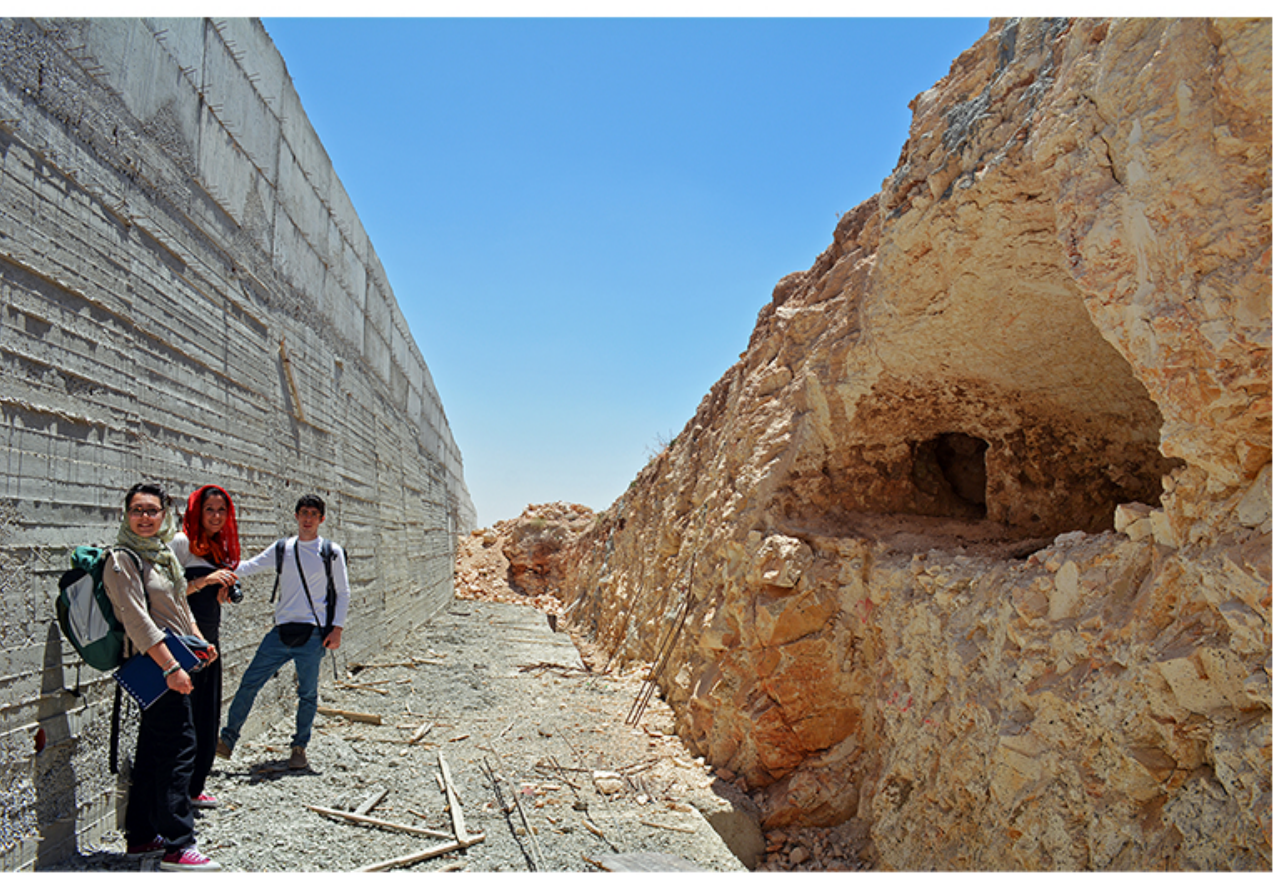

ROMA 2015 


\section{VICINO ORIENTE XIX - 2015}


VICINO ORIENTE

SAPIENZA UNIVERSITÀ DI ROMA

DIPARTIMENTO SCIENZE DELL'ANTICHITÀ

SEZIONE DI ORIENTALISTICA

Scientific Editor: Lorenzo Nigro

International Scientific Committee: Brian Rose, Frank Braemer, Mounir Fantar, Piero Bartoloni, Thomas Schaefer, Zeidan Kafafi

National Scientific Committee: Carlo Giovanni Cereti, Maria Vittoria Fontana, Sebastiano Tusa, Massimiliano Marazzi

Editorial Board: Daria Montanari, Chiara Fiaccavento

Tipografia: SK7 - Roma

ISSN 0393-0300

Rivista con comitato di referee

Journal with international referee system

www.lasapienzatojericho.it/SitoRivista/Journal/Rivista.php

In copertina: Tomba B9, necropoli di Khalet al-Jam’a (Betlemme). 
VICINO ORIENTE

SAPIENZA UNIVERSITÀ DI ROMA

DIPARTIMENTO SCIENZE DELL'ANTICHITÀ

SEZIONE DI ORIENTALISTICA

\section{SOMMARIO}

ARTICOLI

L. Nigro - Bethlehem in the Bronze and Iron Ages

in the light of recent discoveries by the Palestinian MOTA-DACH

V. Pisaniello - Parallel passages among Hittite-Luwian rituals:

for the restoration of KUB 35.146

F. Spagnoli - Una testa di sileno in bronzo da Mozia

N. Chiarenza - Una matrice per terrecotte con sileno dall'Area sacra del Kothon a Mozia

G. Labisi - al-Fudayn: an Umayyad residence in Northern Jordan

P. Buzi - Early Christianity in the Fayyūm: the new contribution of archaeology

I. Materia - Preliminary notes on the ware depicted on the ceiling

of the Cappella Palatina in Palermo

S. Autiero - Indian Ocean trade:

a reassessment of the pottery finds from a multidisciplinary point of view ( $3^{\text {rd }}$ century $B C-5^{\text {th }}$ century $\left.A D\right)$

M.M. Jamhawi - N. Al-Shakarchi - I. Al-Hashimi

Assessment of tourists' satisfaction in the downtown of Amman

SCAVI E RICERCHE

L. Nigro - C. Fiaccavento - M. Jaradat - J. Yasine Archaeology from A to Z: Abu Zarad, an ancient town in the heartland of Palestine

L. Nigro - D. Montanari - M. Ghayyada - J. Yasine

Khalet al-Jam'a. A Middle Bronze and Iron Age necropolis near Bethlehem (Palestine) 185 
VICINO ORIENTE

SAPIENZA UNIVERSITÀ DI ROMA

DIPARTIMENTO SCIENZE DELL'ANTICHITÀ

SEZIONE DI ORIENTALISTICA

L. Nigro - G. Ripepi - I. Hamdan - J. Yasine

The Jericho Oasis Archaeological Park - 2015 Interim Report.

Italian-Palestinian Cooperation for protection

and valorization of archaeological heritage

R. Francia - L'archivio di tavolette del complesso B-C-H di Büyükkale

e l'organizzazione degli archivi reali ittiti. Considerazioni preliminari

V. Pisaniello - La collezione di tavolette del complesso B-C-H di Büyükkale

T. De Vincenzi - L'archivio di tavolette del complesso B-C-H sull'acropoli di Büyükkale

Museo del Vicino ORIente, Egitto e MediterRaneo

L. Nigro - Il nuovo allestimento del Museo del Vicino Oriente,

Egitto e Mediterraneo della Sapienza

D. Montanari - Bollettino delle attività del Museo del Vicino Oriente,

Egitto e Mediterraneo della Sapienza, anno 2015

\section{RECENSIONI}

A. Orsingher - E. PAPPA (2013), Early Iron Age Exchange in the West:

Phoenicians in the Mediterranean and the Atlantic

(Ancient Near Eastern Studies Supplement Series 43),

Leuven - Paris - Walpole 2013, MA.: Peeters 